J. Asiat. Soc. Bangladesh, Sci. 45(1): 127-136, June, 2019

\title{
ESTIMATION OF CARBON STOCK IN THE PEAT SOILS OF BANGLADESH
}

\author{
M. J. UDDIN* AND A.S.M. MOHIUDDIN \\ Department of Soil, Water and Environment, University of Dhaka, \\ Dhaka-1000, Bangladesh
}

\begin{abstract}
There are a very few study on the estimation of carbon stocks in the peat soils of Bangladesh. There are three categories of peat soils in Bangladesh: Sapric peat, Hemic peat and Fibric peat. A study was conducted in these three kinds of peat soils at $100 \mathrm{~cm}$ depths regarding their stock. The study shows that the carbon in peat soils is about 0.12 $\mathrm{Pg}$ whereas it was about $0.25 \mathrm{Pg}$ during 1970s. So, it was found that soil organic carbon loss is alarming and it has been reduced by half during 50 years of agricultural intensification in Bangladesh. These peat soils are losing their carbon due to the decrease of inundation level by climate change, intensive agricultural use and even fuel use for cooking purposes by the local stakeholders. So, it is very much urgent to take steps in preserving the peat soils of Bangladesh.
\end{abstract}

Key words: Estimation, Carbon stock, Peat soils

\section{Introduction}

Peatlands occupy approximately $3 \%$ of global land area, but this storage is roughly $30 \%$ of the world's soil carbon (Gorham 1991, Bridgham et al. 1995, Limpens et al. 2008). Therefore, peatlands represent an important long-term sink for atmospheric carbon dioxide $\left(\mathrm{CO}_{2}\right)$ some of which is released following drainage and land use change. The restoration of peatland ecosystem functions has been suggested as one of the most costeffective ways of reducing greenhouse gas (GHGs) and mitigating the effects of climate change.

Tropical wetland forests containing organic soils - mangroves and freshwater peat swamps- are significant global carbon stores (Donato et al. 2011). Page et al. (2011) estimated $88.6 \mathrm{Pg}$ are stored in tropical peatlands worldwide, with $68.5 \mathrm{PgC}(77 \%)$ occurring in Southeast Asia. Similarly, Donato et al. (2011) estimated mangroves may contain up to $20 \mathrm{Pg} \mathrm{C}$ globally. Tropical wetland forests are susceptible to large scale $\mathrm{C}$ losses, due to their high $\mathrm{C}$ storage and rapid rates of deforestation (Langner et al. 2007, Miettinen and Liew $2010 \mathrm{a}, \mathrm{b}$ ). Further concern is the vulnerability of tropical wetland

\footnotetext{
*Author for correspondence: <mjuddin66@yahoo.com>.
} 
C pools exacerbated by predicted consequences of global climate change: ENSO-related droughts and subsequent fires, altered precipitation patterns, increasing frequency and severity of tropical cyclones and sea level rise (Ellison and Stoddart 1991, Li et al. 2007, Field et al. 2009).

Land conversion on peatlands results in immediate massive $\mathrm{C}$ fluxes to the atmosphere due to drainage, deforestation and burning followed by longer-term oxidative losses contingent on hydrological conditions (Hooijer et al. 2010, Murdiyarso et al. 2010, Hergoualc'h and Verchot 2011). Murdiyarso et al. (2010) estimated that $25 \%$ of all C emissions from converting peat forest to industrial plantation (a dominant land use transition of tropical peatlands in Indonesia; Miettinen et al. 2012) occur from initial burning to clear land. Each year, large areas of peatlands burn throughout Indonesia with fire recurring frequently in areas where peat is drained and degraded. During the unusually severe fire season of 1997, drought conditions prompted opportunistic and uncontrolled burning which eventually affected over 2 Mha of wetland ecosystems throughout Indonesia, resulting in $\mathrm{C}$ losses commensurate with the $1.5 \mathrm{Pg} \mathrm{C}$ average annual flux from global land use change from 1990 - 2005 (Taconni 2003, Page et al. 2002, Langmann and Heil 2004).

There are a very few study on the estimation carbon stocks in the peat soils of Bangladesh. Peat soils are the major store house of organic carbon where there is a scope to use this carbon and energy in mitigating climate change. In the developed countries, peat soils are used in various ways of climate change mitigation. In Bangladesh, exploration of this resource may provide valuable information regarding its usage by estimating the storage. On the other hand, possibly due to the decrease of inundation level in Bangladesh and consequent intensive agricultural usage (Brammer 2002), the peat soils are losing its carbon contents, and thus peat land ecosystems are degrading. So, exploring the carbon storage as well as its sustainable usage is very much important in the recent days. In this connection, an attempt has been undertaken to estimate carbon stock in the peat soils of Bangladesh under present situation of climate change.

\section{Materials and Methods}

Three soil profiles were selected covering the peat land soils of Bangladesh. There are a total of 9 profiles of peat in Bangladesh (Table 1). The selection of the soil profiles were done based on the sapric peat, hemic peat and fibric peat. Soil color study in the field recognized the nature of peat (Table 2). It may be noted that out of 9 profiles, 3 cover Sapric peat or (well decomposed peat with fibre content less than 15\%) profiles 
representing 3 soil series: Hakaluki, Satgaon and Sarail etc. Similarly; Hemic peat or (half decomposed peat with fibre content 15 - 75\%) profiles cover the 3 soil series: Rajoir, Satla and Mohonganj; and the fibric peat (immature peat with fibre content greater than $75 \%$ ) or profiles cover the 3 soil series: Harta, Juri and Tarala etc.

Table 1. A list peat basin soils of Bangladesh along with their areas and USDA names.

\begin{tabular}{lll}
\hline Soil series & Areas (ha) & USDA names \\
\hline Hakaluki & 4,953 & Fluvaquantic Haplosaprists \\
Sarail & 595 & Typic Haplosaprists \\
Satgaon & 722 & Fluventic Haplosaprists \\
Rajoir & 18,412 & Typic Haplohemists \\
Satla & 48,505 & Typic Haplohemists \\
Mohanganj & 4,930 & Hydric Haplohemists \\
Harta & 44,273 & Typic Haplofibrists \\
Juri & 2,035 & Hydric Haplofibrists \\
Tarala & 604 & Hydric Haplofibrists \\
\hline
\end{tabular}

Source: Rahman 2005, Hussain et al. 2003.

Table 2. Indicators used for differentiating peat maturity in the field.

\begin{tabular}{llll}
\hline Indicators & $\begin{array}{l}\text { Fibric (immature) } \\
\text { peat }\end{array}$ & $\begin{array}{l}\text { Hemic (medium } \\
\text { maturity) peat }\end{array}$ & $\begin{array}{l}\text { Sapric (mature) } \\
\text { peat }\end{array}$ \\
\hline $\begin{array}{l}\text { Decomposition } \\
\text { stage }\end{array}$ & $\begin{array}{l}\text { Peat at early } \\
\text { decomposition stage, } \\
\text { with its original } \\
\text { materials still } \\
\text { recognizable. }\end{array}$ & $\begin{array}{l}\text { Half-decomposed } \\
\text { peats, with some } \\
\text { original materials are } \\
\text { still recognizable. }\end{array}$ & $\begin{array}{l}\text { Decomposed peat in } \\
\text { which the original } \\
\text { materials are no } \\
\text { longer recognizable. }\end{array}$ \\
$\begin{array}{l}\text { Brown-light brown } \\
\begin{array}{l}\text { When squeezed in } \\
\text { the palm, the } \\
\text { amount of fiber } \\
\text { remained }\end{array}\end{array}$ & $\begin{array}{l}\text { More than two-thirds } \\
\text { of the initial amount. }\end{array}$ & $\begin{array}{l}\text { One-to-two-thirds of } \\
\text { the initial amount. }\end{array}$ & $\begin{array}{l}\text { Less than one-third of } \\
\text { the initial amount. }\end{array}$ \\
\hline
\end{tabular}

Soil samples from a depth of $1 \mathrm{~m}$ of all three profiles were collected in thick polythene bags. The soil samples were air dried under shade. The samples were then gently ground with rolling wooden rod and also with a wooden hammer and passed through $0.5 \mathrm{~mm}$ sieve and mixed thoroughly. The samples were then preserved in plastic bags for $\mathrm{C}$ analysis. 
Soil organic carbon was determined by the wet oxidation method of Walkley and Black (1934) as described by Nelson and Sommers (1982). Bulk density was measured by core method as described by Blake and Hartge (1986). The total soil organic carbon (TSOC) stock or storage was calculated using the equations of Batjes (1996), Chen et al. (2007), Zhang et al. (2013). It may be noted that the bulk density and SOC concentration (\%) are the two prerequisites for estimating SOC stock or storage. Thus, the SOC storage was calculated using the following equations (Batjes 1996, Chen et al. 2007, Zhang et al. 2013).

Total soil organic carbon $(\mathrm{TSOC})=\mathrm{SOC}_{\mathrm{i}} \times \mathrm{B}_{\mathrm{i}} \times \mathrm{D}_{\mathrm{i}}$

where, $\mathrm{SOC}_{\mathrm{i}}$ is the SOC content on the $\mathrm{i}^{\text {th }}$ layer $(\mathrm{g} / \mathrm{kg})$;

$\mathrm{B}_{\mathrm{i}}$ is the bulk density of the $\mathrm{i}^{\text {th }}$ layer $(\mathrm{g} / \mathrm{cc})$, and $\mathrm{D}_{\mathrm{i}}$ is the depth of the $\mathrm{i}^{\text {th }}$ layer $(\mathrm{cm})$.

\section{Results and Discussion}

Guidelines for estimating greenhouse gas (GHG's) emissions from agriculture, forestry, and other land uses are provided by the Intergovernmental Panel on Climate Change (IPCC). The IPCC guidance includes specific details for estimating $\mathrm{C}$ stocks of upland forest ecosystems; however, specific provisions for tropical wetland organic soils and peatlands are seriously lacking (IPCC 2006). The close relationship between C density and bulk density allows for a reasonably accurate estimation of peat $\mathrm{C}$ stocks for tropical organic soils.

Eswaran et al. (1995) estimated soil organic carbon contents in the soil orders at global level. From the above data sets, Hussain (2002) estimated that the soils of Bangladesh have a total of 2.2 Pg of organic carbon. The Histosols in Bangladesh occupy an area of slightly more than a million ha and it contains 0.25 Pg organic C (Table 3). Possibly, this is the base line data sets of organic carbon mass in the soils of Bangladesh. There is a serious lacking of SOC stock or storage data sets in Bangladesh even for peat soils. This quantity of organic carbon present in the Histosols may be significant as $\mathrm{C}$ sink. But at present, these peats are used for agriculture as well as fuel where $\mathrm{C}$ is released to the air after the decomposition of peat. In the tropics, most Histosols are still under forest, though most of them are cleared for agriculture and other purposes.

The mean bulk density distribution in the Hakaluki and Rajoir soil (ranges from 0.62$0.63 \mathrm{~g} / \mathrm{cc})$ is more or less same where as in Harta soil $(0.53 \mathrm{~g} / \mathrm{cc})$, it is lower than the other two soils (Table 4). Agus et al. (2011) noted that the range of peat soil bulk density is generally about $0.02-0.30 \mathrm{~g} / \mathrm{cc}$ depending on the maturity, compaction as well as the ash 
contents. They also reported that on average bulk density for Southeast Asia peatlands indicates a broad range and considerable variation depending on its land uses. In Bangladesh, peatlands are mostly used for Boro rice, shrimp and vegetable where there is a little scope of soil carbon sink.

Table 3. Organic carbon mass in the soils of the world and of Bangladesh.

\begin{tabular}{lccccccc}
\hline \multirow{2}{*}{$\begin{array}{l}\text { Soil } \\
\text { orders }\end{array}$} & Global & Tropical & Bangladesh & & Global & Tropical & Bangladesh** \\
\cline { 2 - 4 } \cline { 7 - 8 } Entisols & 14921 & 3256 & 14.2 & & 148 & 19 & 0.14 \\
Inceptisols & 21580 & 4565 & 97.5 & & 352 & 60 & 1.59 \\
Ultisols & 11330 & 9018 & 0.89 & & 105 & 85 & 0.08 \\
Histosols & $\mathbf{1 7 4 5}$ & $\mathbf{2 8 6}$ & $\mathbf{1 . 2}$ & & $\mathbf{3 5 7}$ & $\mathbf{1 0 0}$ & $\mathbf{0 . 2 5}$ \\
Alfisols & 18283 & 6411 & 1.2 & & 127 & 30 & 0.03 \\
Misc. land & 7644 & 1358 & 24.0 & & 18 & 2 & 0.05 \\
Total & - & - & 147.0 & & - & - & 2.20 \\
\hline
\end{tabular}

$* \operatorname{Pg}=$ Petagram $=1 \times 10^{15}$ (Source: Eswaran et al. 1995); Hussain 2002**

Table 4. Bulk density distribution (g/cc) at different soil depths across the peat soils.

\begin{tabular}{lccc}
\hline Depths $(\mathrm{cm})$ & Harta & Hakaluki & Rajoir \\
\hline $0-20$ & 0.88 & 0.91 & 0.90 \\
$20-40$ & 0.65 & 0.85 & 0.90 \\
$40-60$ & 0.60 & 0.65 & 0.52 \\
$60-80$ & 0.28 & 0.40 & 0.50 \\
$80-100$ & 0.28 & 0.30 & 0.35 \\
Mean & 0.53 & 0.62 & 0.63 \\
\hline
\end{tabular}

Soil organic carbon (SOC) distribution in the Harta soils ranges from 10.09 to 21.53 per cent from surface to $100 \mathrm{~cm}$ depth and the mean organic carbon is 15.03 per cent (Table 5). Soil organic carbon distribution in the Hakaluki soils ranges from 6.63 to 15.01 per cent from surface to $100 \mathrm{~cm}$ depths and the mean organic carbon is 11.18 per cent. Soil organic carbon distribution in the Rajoir soils ranges from 12.10 to 28.20 per cent from surface to 100 depths and the mean organic carbon is 20.66 per cent. So, the soil organic carbon distribution in the peat soils of the study site ranges from 11.18 to 20.66 per cent (Table 5).

Agus et al. (2011) reported that peat soils contain 18 - 58\% carbon. They also reported that in Southeast Asia, soil organic carbon in peat lands varies in a broad range and 
considerable variation depends on their local land uses, land covers and land conditions. In Bangladesh, peatlands are mostly used for agricultural purposes where there is a considerable loss of organic carbon rather than sink. On the other hand, there is no forest cover in the peatlands of Bangladesh as such diversified use of peatland is limited.

Table 5. Soil organic carbon distribution $(\%)$ at different soil depths across the peat soils.

\begin{tabular}{lccc}
\hline Depths $(\mathrm{cm})$ & Harta & Hakaluki & Rajoir \\
\hline $0-20$ & 10.09 & 6.63 & 12.10 \\
$20-40$ & 11.24 & 8.83 & 12.59 \\
$40-60$ & 12.21 & 10.54 & 24.20 \\
$60-80$ & 20.12 & 14.91 & 26.21 \\
$80-100$ & 21.53 & 15.01 & 28.20 \\
Mean & 15.03 & 11.18 & 20.66 \\
\hline
\end{tabular}

Soil organic carbon storage in the Harta soils varies from 11.27 to $17.76 \mathrm{~kg} / \mathrm{m}^{2}$ and the total storage is about $14.07 \mathrm{~kg} / \mathrm{m}^{2}$ up to $100 \mathrm{~cm}$ depth of the soil (Table 6). Harta soils are mainly dominated by the rice-shrimp integrated cultivation. Soil organic carbon storage in the Hakaluki soils varies from 9.00 to $15.01 \mathrm{~kg} / \mathrm{m}^{2}$ and the total storage is about 12.34 $\mathrm{kg} / \mathrm{m}^{2}$. Hakaluki soils are used for the cultivation of Boro rice and in the dry season these are used for grazing grass land. Soil organic carbon storage in the Rajoir soils varies from 19.75 to $26.21 \mathrm{~kg} / \mathrm{m}^{2}$ and the total storage is about $23.11 \mathrm{~kg} / \mathrm{m}^{2}$. Rajoir soils are used for the cultivation Boro rice and it remains waterlogged almost for the whole year. So, it was found that soil organic carbon storage in the study sites varies from 12.34 to $23.11 \mathrm{~kg} / \mathrm{m}^{2}$ (Table 6). The variation in the soil organic carbon storage possibly due to the land use, inundation level and land cover variations.

Table 6. Soil organic carbon storage $\left(\mathrm{kg} / \mathrm{m}^{2}\right)$ at different soil depths across the peat soils.

\begin{tabular}{lccc}
\hline Depths $(\mathrm{cm})$ & Harta & Hakaluki & Rajoir \\
\hline $0-20$ & 17.76 & 12.06 & 21.78 \\
$20-40$ & 14.62 & 15.01 & 22.66 \\
$40-60$ & 14.65 & 13.70 & 25.17 \\
$60-80$ & 11.27 & 11.92 & 26.21 \\
$80-100$ & 12.05 & 9.00 & 19.75 \\
Mean SOC Kg/ m ${ }^{2}$ & 14.07 & 12.34 & 23.11 \\
\hline
\end{tabular}

Soil organic carbon stock across the peat soils of Bangladesh at $100 \mathrm{~cm}$ depths was estimated to be about $0.12 \mathrm{Pg}$ (Table 7) which is very low in relation to other tropical 
countries. It was reported in 1970s that C stock across the peat soils of Bangladesh was about $0.25 \mathrm{Pg}$. The increasing demand for land resources has led to a high pressure for the use of peatlands for producing agricultural commodities. Thus, the conversion and draining of peat to create favorable conditions for aerobic crops, changed the role of peat land from $\mathrm{C}$ sink to $\mathrm{C}$ loss. Long-term drainage and conversion to farmland of peatlands has repeatedly caused major subsidence and carbon loss (Hutchinson 1980). On the other hand, peat fire for fuel purpose by the local stake holders in the dry season becomes more prevalent in some areas of Bangladesh which makes $\mathrm{CO}_{2}$ emissions. Due to the long-term inundation, peat surface subsides; it loses its functions as the $\mathrm{C}$ storage and hydrological condition control which stores water during the rainy season and releases it gradually during the dry season. Thus, subsidence in the dry season is associated with peat compaction, and $\mathrm{CO}_{2}$ emissions.

Table 7. Carbon stock (Pg) across the peat soils of Bangladesh at $100 \mathrm{~cm}$ depths.

\begin{tabular}{lcc}
\hline Soil series & Areas (ha) & SOC stock $(\mathrm{Pg})$ \\
\hline Hakaluki & 4,953 & 0.0031 \\
Sarail & 595 & 0.0003 \\
Satgaon & 722 & 0.0004 \\
Rajoir & 18,412 & 0.1202 \\
Satla & 48,505 & 0.0560 \\
Mohanganj & 4,930 & 0.0056 \\
Harta & 44,273 & 0.0315 \\
Juri & 2,035 & 0.0014 \\
Tarala & 604 & 0.0004 \\
Total & $1,25,029$ & 0.1202 \\
\hline
\end{tabular}

There are several factors that alter the function of peat land from a sink into a $\mathrm{CO}_{2}$ source which are most common in Bangladesh.

1. Land clearing that increases the amount of sunlight onto the peat surface so that soil temperature and the activity of decomposing microorganisms increase. Water hyacinth and rice straw increases the availability of fresh organic matter that easily decomposes into $\mathrm{CO}_{2}$ under aerobic, and $\mathrm{CH}_{4}$ under anaerobic conditions.

2. Drainage that decreases the peat water table on the site and surrounding areas that are under agricultural crops/covers. Drainage changes the soil conditions from anaerobic to aerobic and increases $\mathrm{CO}_{2}$ emissions. 
3. Collection of peat in the dry season for fuel increases $\mathrm{CO}_{2}$ emissions owing to burning or oxidation of one or a combination of plant biomass, and peat layers. Fires often occur during land-use change from forest to agriculture or other land uses in the tropical countries. Fires also occur during long drought periods. Under traditional farming practices, burning are done to reduce soil acidity and improving soil fertility. But, on the other hand, this practice increases the contribution of peat to $\mathrm{CO}_{2}$ emissions.

4. The addition of fertilizers such as nitrogen fertilizers lowers the $\mathrm{C} / \mathrm{N}$ ratio of soil and encourages the decomposition of organic matter by microorganisms, followed by the release of $\mathrm{CO}_{2}$. Nitrogen fertilizer also contributes to $\mathrm{N}_{2} \mathrm{O}$ emission. Fertilizing with manure or the addition of ameliorants that increase the $\mathrm{pH}$ of peat may also accelerate peat decomposition.

These soils can be improved by allowing sediments from the adjoining tidal rivers to settle on the peat basins. This sedimentation process should be continued for several years to develop the land for agricultural purposes. Peatland is an important carbon and water storage and the loss of these functions due to drainage has become a national and global concern. However, the activity of peat fire, loss of water table depth as well as carbon emission is hot issue now-a-days under recent situation of climate change. These strongly suggest research on this aspect. Technical, incentives and regulatory measures must be enhanced to make the best benefits of the use of peatland. Furthermore, exploration of economically competitive crops under un-drained system should also be prioritized.

\section{References}

Agus, F., K. Hairiah and A. Mulyani. 2011. Measuring C stock in peat soils. Practical Guidelines.Bogor, Indonesia. World Agroforestry Centre Southeast Asia regional program. Indonesian Center for Agricultural Land Resources Research and Development. 60 pp.

Batjes, N. H. 1996. The total C and N in soils of the world. Eur. J. Soil Sci. (June). 47: 151-163.

Blake, G.H. and K. H. Hartge. 1986. Bulk density. In: Klute, A. (ed.), Methods of Soil Analysis Am. Soc. Agron. 2nd ed. Agron. No. 9(Part I): 363-375. Madison, USA.

Brammer, H. 2002. Land use and land use planning in Bangladesh. The University Press Limited. pp. 179-181.

Bridgham, S. D., C. A. Johnston, J. Pastor and K. Updegraff. 1995. Potential feedbacks of Northern wetlands on climate change. Bioscience. 45: 262-274.

Chen, L.D., J. Gong, B. J. Fu, Z. L. Huang, Y. L. Huang and L. D. Gui. 2007. Effect of land use conversion on soil organic carbon sequestration in the Loess hilly area, loess plateau of China. Ecol. Res. 22: 641-648. 
Estimation of carbon stock in the peat soils

Donato, D. C., J. B. Kauffman, D. Murdiyarso, S. Kurnianto, M. Stidham and M. Kanninen. 2011. Mangroves among the most carbon rich forests in the tropics. Nat. Geosci. 4: 293-297.

Ellison, J. C. and D. R. Stoddart. 1991. Mangrove ecosystem collapse during predicted sea-level rise: Holocene analogues and implications. J. Coastal Res. 7: 151-165.

Eswaran, H., E. V. D. Berg, and P. Reich. 1995. Organic C in soils of the World. Soil Sci. Soc. Am. J. 57: 192-194.

Field, R. D., G. R. van der Werf and S.S.P. Shen. 2009. Human amplification of drought-induced biomass burning in Indonesia since 1960. Macmillan Publishers Limited. Nat. Geosci. Letters 2: $185-188$.

Gorham, E. 1991. Northern peat lands: Role in the carbon cycle and probable responses toclimatic warming. Ecological Applications. 1: 182-195.

Hergoualc'h, K. and L. V. Verchot. 2011. Stocks and fluxes of carbon associated with land use change In: Southeast Asian tropical peat lands: a review. Glob. Biogeochem. Cycles. Doi: 10.1029/2009GB003718.

Hooijer, A., S. Page, J. G. Canadell, M. Silvius, J. Kwadijk, H. Wosten and J. Jauhiainen. 2010. Current and future $\mathrm{CO}_{2}$ emissions from drained peat lands in Southeast Asia. Biogeosciences. 7: 1505-1514.

Hussain, M. S. 2002. Distribution of organic carbon and its sequestration in the soils of theBengal Delta. The Delta Research Centre, Department of Geology. University of Dhaka. Bangladesh. $52 \mathrm{p}$.

Hussain, M. S., S. F. Elahi, H. Eswaran, M. J. Uddin and S. Islam. 2003. Bangladesh: In Quest of Resource Management Domains. GIS laboratory publication No. 2. Department of Soil, Water and Environment, University of Dhaka. Bangladesh.

Hutchinson, J. N. 1980. The record of peat wastage in the east Anglian fenlands at Holme Post, 1848-1978 A.D. Jour. Ecology. 68: 229-249.

IPCC, 2006. Guidelines for Natural Greenhouse Gas Inventories. In: Volume 4, Agriculture, Forestry and Other Land Use. (Eds.): Eggleston, H. S., Buendia, L., Miwa, K., Ngara, T. and Tanabe, K., IGES, Japan.

Langmann, B. and A. Heil. 2004. Release and dispersion of vegetation and peat fireemissions in the atmosphere over Indonesia 1997-98. Atmos. Chem. Phys. 4: 2145-60.

Langner, A., J. Miettinen and F. Siegert. 2007. Land cover change 2002-05 in Borneo and the role of fire derived from MODIS imagery. Glob. Change Biol. 13: 2329-2340.

Li, W., R. E. Dickinson, R. Fu, G. Niu, Z. Yang and J.G. Canadell. 2007. Future. precipitation changes and their implications for tropical peat lands. American Geophysical Union. Geophys. Res. Lett. 34: L01403. Doi:10.1029/2006GL028364.

Limpens, J., F. Berendse, C. Blodau, J. G. Canadell, C. Freeman, J. Holden, N. Roulet, H. Rydin and G. Schaepman-strub. 2008. Peat lands and the carbon cycle: from local processes to global implications - a synthesis. Biogesciences. 5: 1475-1491.

Miettinen, J. and S. C. Liew. 2010a. Status of peat land degradation and development in Sumatra and Kalimantan. Ambio. 39: 394-401

Miettenen, J. and S. C. Liew. 2010b. Degradation and development of peat lands in Peninsular Malaysia and in the islands of Sumatra and Borneo since 1990. Land Degrad. Dev. 21: 285296.

Miettinen, J., C. Shi, W. J. Tan, and S. C. Liew. 2012. 2010 Land cover map of insular Southeast Asia in $250 \mathrm{~m}$ spatial resolution. Remote Sensing Lett. 3: 11-20.

Murdiyarso, D., K. Hergoualc'h and L. V. Verchot. 2010. Opportunities for reducing greenhouse gas emissions in tropical peat lands. P. Natl. Acad. Sci. USA. 107: 19655-660.

Nelson, D.W. and L. W. Sommers. 1982. Total carbon, organic carbon and organic matter. pp. 539- 577. In: Page, A.L., Miller, R.H., Keeney, D.R. (eds.). Methods of Soil Analysis. Part 2. Agronomy monograph, 2nd edition, ASA and SSSA. Inc. Madison, Wisconsin, USA. 
Page, S. E., F. Siegert, J. O. Rieley, H. D. V. Boehm, A. Jaya and S. H. Limin. 2002. The amount of carbon released from peat and forest fires in Indonesia during 1997. Nature, 420: 61-65.

Page, S. E., J. O. Rieley and C. J. Banks. 2011. Global and regional importance of the tropical peat land carbon pool. Glob. Change Biol. 17: 798-818.

Rahman, M. R. 2005. Soils of Bangladesh. Darpan Publications Limited, Bangladesh.

Taconni, L. 2003. Fires in Indonesia: causes, costs, and policy implications. CIFOR Occasional paper No. 38. Centre for International Forestry Research, Bogor, Indonesia.

Walkley, A. and I. A. Black. 1934. An examination of the Degtjareff method for determining soil organic matter and a proposed modification of the chromic acid titration method. Soil Sci. 37: 29-38.

Zhang, C., G. Liu, S. Xue and C. Sun. 2013. Soil organic carbon and total nitrogen storage as affected by land use in a small watershed of the loess plateau, China. European J. Soil Biol. 54: 16-24.

(Revised copy received on 25.03.2019) 